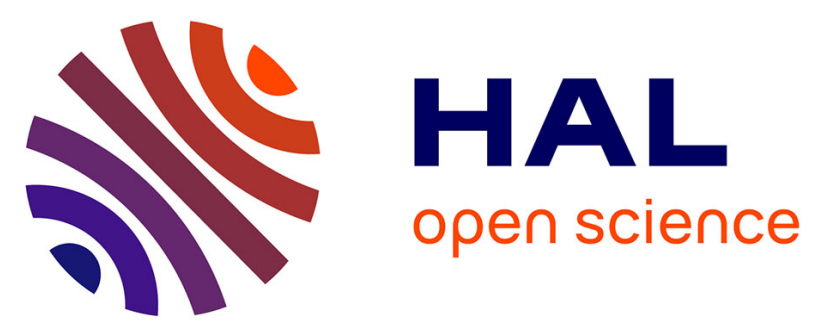

\title{
High-resolution quantification of earthworm calcite granules from western European loess sequences reveals stadial-interstadial climatic variability during the Last Glacial
}

\author{
Charlotte Prud'Homme, Olivier Moine, Jérôme Mathieu, Segolene \\ Saulnier-Copard, Pierre Antoine
}

\section{To cite this version:}

Charlotte Prud'Homme, Olivier Moine, Jérôme Mathieu, Segolene Saulnier-Copard, Pierre Antoine. High-resolution quantification of earthworm calcite granules from western European loess sequences reveals stadial-interstadial climatic variability during the Last Glacial. Boreas, 2019, 48 (1), pp.257268. 10.1111/bor.12359 . hal-02147883

\section{HAL Id: hal-02147883 \\ https://hal.sorbonne-universite.fr/hal-02147883}

Submitted on 15 Dec 2021

HAL is a multi-disciplinary open access archive for the deposit and dissemination of scientific research documents, whether they are published or not. The documents may come from teaching and research institutions in France or abroad, or from public or private research centers.
L'archive ouverte pluridisciplinaire HAL, est destinée au dépôt et à la diffusion de documents scientifiques de niveau recherche, publiés ou non, émanant des établissements d'enseignement et de recherche français ou étrangers, des laboratoires publics ou privés. 


\section{High-resolution quantification of earthworm calcite granules from western European loess sequences reveals stadial-interstadial climatic variability during the Last Glacial}

CHARLOTTE PRUD'HOMME ID, OLIVIER MOINE, JEROME MATHIEU, SEGOLENE SAULNIER-COPARD AND PIERRE
ANTOINE

BOREAS

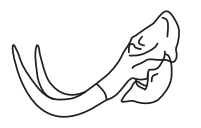

Prud'homme, C., Moine, O., Mathieu, J., Saulnier-Copard, S. \& Antoine, P.: High-resolution quantification of earthworm calcite granules from western European loess sequences reveals stadial-interstadial climatic variability during the Last Glacial. Boreas. https://doi.org/10.1111/bor.12359. ISSN 0300-9483.

High concentrations of calcite fossil granules produced by earthworms (ECG) have been identified in most of the stratigraphical units along the loess-palaeosol reference sequence of Nussloch (Germany). They are particularly abundant in interstadial brown soils and in tundra gley horizons, the latter reflecting short-term phases of aggradation then degradation of permafrost. These granules are characterized by a radial crystalline structure produced in the earthworms by specific bio-mineralization processes. In our study, we used this biological indicator combined with ${ }^{14} \mathrm{C}$ and OSL dating, and sedimentological parameters to characterize millennial-time scale climatic variations recorded in loess sequences. The approach is based on high-resolution counts of ECG throughout a $17-\mathrm{m}$-thick loess sequence (332 samples). Strong increases in granule and mollusc concentrations suggest warmer climate conditions during palaeosol formation phases, associated with increasing biodiversity, biological activity and vegetation cover. Decreased granule concentrations occur within primary loess deposits, indicating a strong correlation with palaeoenvironmental conditions and demonstrating the reliability of ECG concentration variations as a new palaeoenvironmental proxy. Finally, this pattern is also recorded in loess sequences located about $600 \mathrm{~km}$ westward in northern France demonstrating the large-scale validity of this new palaeoclimatic proxy.

Charlotte Prud'homme (c.prudhomme@mpic.de), Laboratoire de Géographie Physique, Environnements Quaternaires et Actuels, (LGP), UMR 8591 CNRS-Université Paris 1-UPEC, 1 Place Aristide Briand 92195 Meudon cedex, France and Research Group for Terrestrial Palaeoclimates, Max Planck Institute for Chemistry, Hahn-Meitner-Weg 1, Mainz 55128, Germany; Olivier Moine, Ségolène Saulnier-Copard and Pierre Antoine, Laboratoire de Géographie Physique, Environnements Quaternaires et Actuels, (LGP), UMR 8591, CNRS-Université Paris 1-UPEC, 1 Place Aristide Briand 92195 Meudon cedex, France; Jerome Mathieu, Université Pierre-et-Marie-Curie (UPMC) - Institut d'Ecologie et des Sciences de l'Environnement de Paris, Institut de Recherche pour le Développement, Sorbonne Universités, 4 Place Jussieu, Paris 75005, France; received 31 st May 2018, accepted 1st October 2018.

Covering almost all non-glaciated continental areas lower than $500 \mathrm{~m}$ between 42 and $52^{\circ} \mathrm{N}$, the European Loess Belt represents the most extensive terrestrial archive of the Last Glacial (Pecsi 1990; Haase et al. 2007). Its western part is well situated to record the impact of the climatic variations triggered by fluctuations of both North Atlantic oceanic circulation and Fennoscandian sea-ice cover extension propagated eastward by the Westerlies (Renssen et al. 2007; Antoine et al. 2009). The loess sequences of western Europe provide very detailed and reliable records of climatic and 4 environmental changes of the last $110 \mathrm{kyr}$ in the European Plain (Remy 1968; Antoine et al. 2001, 2016; Meijs 2011; Haesaerts et al. 2016; Schirmer 2016). Despite the occurrence of some erosion gaps these sequences, made 5 up of complex and cyclic successions of loess units (aeolian deposits) and of soil horizons, have recorded the impact of millennial-scale climatic variability during the Last Glacial (Antoine et al. 2009, 2016; Moine et al. 2017; Rousseau et al. 2017). They also exhibit high 6 sedimentation rates of up to $1 \mathrm{~mm}$ per year especially between 30 and $20 \mathrm{ka}$ during the Upper Pleniglacial (Meszner et al. 2011, 2013; Antoine et al. 2016). Previously based on pedostratigraphical studies, grain-size analysis, terrestrial mollusc assemblages and OSL dating (Antoine et al. 2002, 2009; Rousseau et al. 2007; Moine et al. 2008; Meijs 2011; Schirmer 2012), correlations of palaeosols with Dansgaard-Oeschger events recorded in Greenland ice-cores have recently been improved by radiocarbon dating performed on earthworm calcite granules (ECG; Moine et al. 2017).

However, as pollen grains are generally not preserved in loess sediments due to their oxidation in this porous sediment, the impact of these millennial climate changes on palaeoenvironment has been until now mainly investigated through the analysis of terrestrial mollusc assemblages (Moine et al. 2005, 2008, 2011). The malacological analysis of Nussloch loess sequences revealed a vegetation cover developed on periglacial deposits (Moine 2008) and confirmed that the formation of palaeosols such as tundra gley horizons is associated with moisture increase. In parallel, a new proxy has been discovered in Quaternary deposits: ECG. Surprisingly, the presence of ECG in Last Glacial loess-palaeosol sequences has been found to be common in many regions from westerncentral Europe (Mazenot 1956; Kerney 1971; Meijer 1985; Becze-Deák et al. 1997; Barta 2014; Prud'homme et al. 2015; Moine et al. 2017). 
ECG are composed of large rhombohedral calcite crystals organized in a radial crystalline structure (Canti 1998; Gago-Duport et al. 2008). They are produced by a biomineralization process within calciferous glands (also called Morren's glands) located in three pairs on each side of the oesophagus (Darwin 1881). This process starts in the four oesophagus pouches (segments XII and XI) with the secretion of a colloidal 'milky' fluid, which contains amorphous calcium carbonate (ACC) crystals of irregular shape and size ranging from 10 to $50 \mu \mathrm{m}$. Then, the milky fluid reaches the two oesophageal pouches in the front (segment X) where the ACC is precipitated into macroscopic crystals of calcium carbonate, which are finally released into the soil through the gut (Briones et al. 2008; Gago-Duport et al. 2008; Hodson et al. 2015). Currently, Lumbricus is identified as the most productive genus (Bräm 1956; Canti 1998; Canti \& Piearce 2003). In vitro experiments showed that this genus releases granules principally at the soil surface in the litter (Canti \& Piearce 2003). However, contrary to the species Eisenia nordenskioldi and Dendrobaena octaedra commonly found in permafrost environments, the Lumbricus genus is not considered as freeze-tolerant (Rasmussen \& Holmstrup 2002; Holmstrup 2003; Calderon et al. 2009). Freeze-tolerant species can endure ice formation in extracellular body due to rapid glucose

9 accumulation in cells. Moreover, Eisenia nordenskioldi and Dendrobaena octaedra belong to the epigeic class (i.e. living at the surface of the soil) whereas Lumbricus terrestris and Lumbricus rubellus belong to the anecic and epi-edogenic classes, respectively (i.e. living beneath the soil surface and able to dig burrows). Thus, their life cycle and behaviour eannet becomparable in the same context. Lumbricus terrestris and Lumbricus rubellus are found up to 60 and $65^{\circ} \mathrm{N}$, respectively, in the central Russian Plain (Tiunov et al. 2006; Meshcheryakova \& Berman 2014) and also in southwestern Finland and southern Sweden (Rundgren 1975; Nuutinen \& Butt 2009). Although they are often absent from modern permafrost environments (Perel' 1979), adult individuals of both species can 2 survive in soil temperatures as low as $-1{ }^{\circ} \mathrm{C}$ (Nordström 1975; Rundgren 1975). Moreover, L. terrestris is able to overwinter in all life stages and its cocoons (i.e. envelopes protecting the eggs) can survive 1 month in frozen soil (Nuutinen \& Butt 2009). Earthworm cocoons resist freezing by cryoprotective dehydration, characterized by a loss of $50 \%$ of the mass of their body fluids (Holmstrup 1994). Even though most earthworm species in western Europe were strongly affected by the Last Glacial (Mathieu \& Davies 2014), the discovery of abundant granules in palaeosols developed during the Weichselian suggests that a few species able to survive in 13 permafrost environment, perhaps even outside refuges. As Lumbricus species are currently very abundant in Germany (Jänsch et al. 2013) and in the absence of other common large taxa known to produce numerous granules in western Europe (Bräm 1956; Canti 1998), we assume that Lumbricus individuals produced the large $(\leq 0.8 \mathrm{~mm})$ granules discovered in the Last Glacial loess sequence of Nussloch.

Previous works showed that ECG: (i) can constitute an ideal material for radiocarbon dating in loess contexts as demonstrated by the new chronology of the Nussloch sequence (Moine et al. 2017), (ii) allow the quantification of palaeoclimatic parameters (temperature and precipitation; Prud'homme et al. 2016, 2018) and (iii) can be used as a bio-indicator for palaeoenvironmental reconstructions (Prud'homme et al. 2015).

In this paper, we focus on the third point above by presenting the first continuous record of ECG concentration variations from the west European reference site of Nussloch. The 17-m-thick loess-palaeosol sequence encompasses the Weichselian Middle and Upper Pleniglacial from about 55 to $20 \mathrm{ka}$. The ECG counting profile is compared with high-resolution stratigraphy and grain-size analysis.

\section{Material and methods}

\section{Stratigraphy}

The Nussloch loess-palaeosol profiles have been studied in an active limestone quarry (latitude $49^{\circ} 18^{\prime} 59^{\prime \prime} \mathrm{N}$, longitude $\left.8^{\circ} 43^{\prime} 54^{\prime \prime} \mathrm{E}\right)$ located at about $10 \mathrm{~km}$ southsoutheast of the city of Heidelberg on the eastern flank of the Upper Rhine valley (Fig. 1). The stratigraphy of the former four main profiles (P1 to P4) has already been published in great detail (Antoine et al. 2001, 2009). These profiles consist of four sub-sequences attributed to the main chronoclimatic phases of the Last Glacial, i.e. Early Glacial, Lower, Middle and Upper Pleniglacial (Antoine et al. 2009). Profile P8, located about $50 \mathrm{~m}$ from the reference profile $\mathrm{P} 4$ in the same loess greda (i.e. elongated loess ridge forms orientated parallel to the direction of winds; Leger 1990), revealed the same stratigraphical succession and can easily be correlated with the other profiles using specific palaeosol marker horizons. Moreover, a radiocarbon chronology based on 46 dates obtained from ECG has been produced for Nussloch profiles P3, P4 and P8 (Moine et al. 2017). This new chronology, combined with some of the previous OSL dates, highlights a very accurate time-framework for the deposition of the Nussloch loess sequence.

According to stratigraphy and sedimentology given in Antoine et al. (2009), the 17-m-thick P8 profile is made up of the succession of two main chronoclimatic phases of the Last Glacial: the lower $5 \mathrm{~m}$ allocated to the Middle Pleniglacial (from $\sim 55$ to $35 \mathrm{ka}$; MIS 3) and the upper $12 \mathrm{~m}$ representing the Upper Pleniglacial (from $\sim 35$ to $20 \mathrm{ka}$; end of MIS 3 and beginning of MIS 2). The lower part is composed of a succession of two thick boreal brown soils (Lower (GBL) and Upper (GBU) Gräselberger Boden) developed on silty aeolian sands, followed by loess and tundra gley horizons, topped by an arctic brown soil 


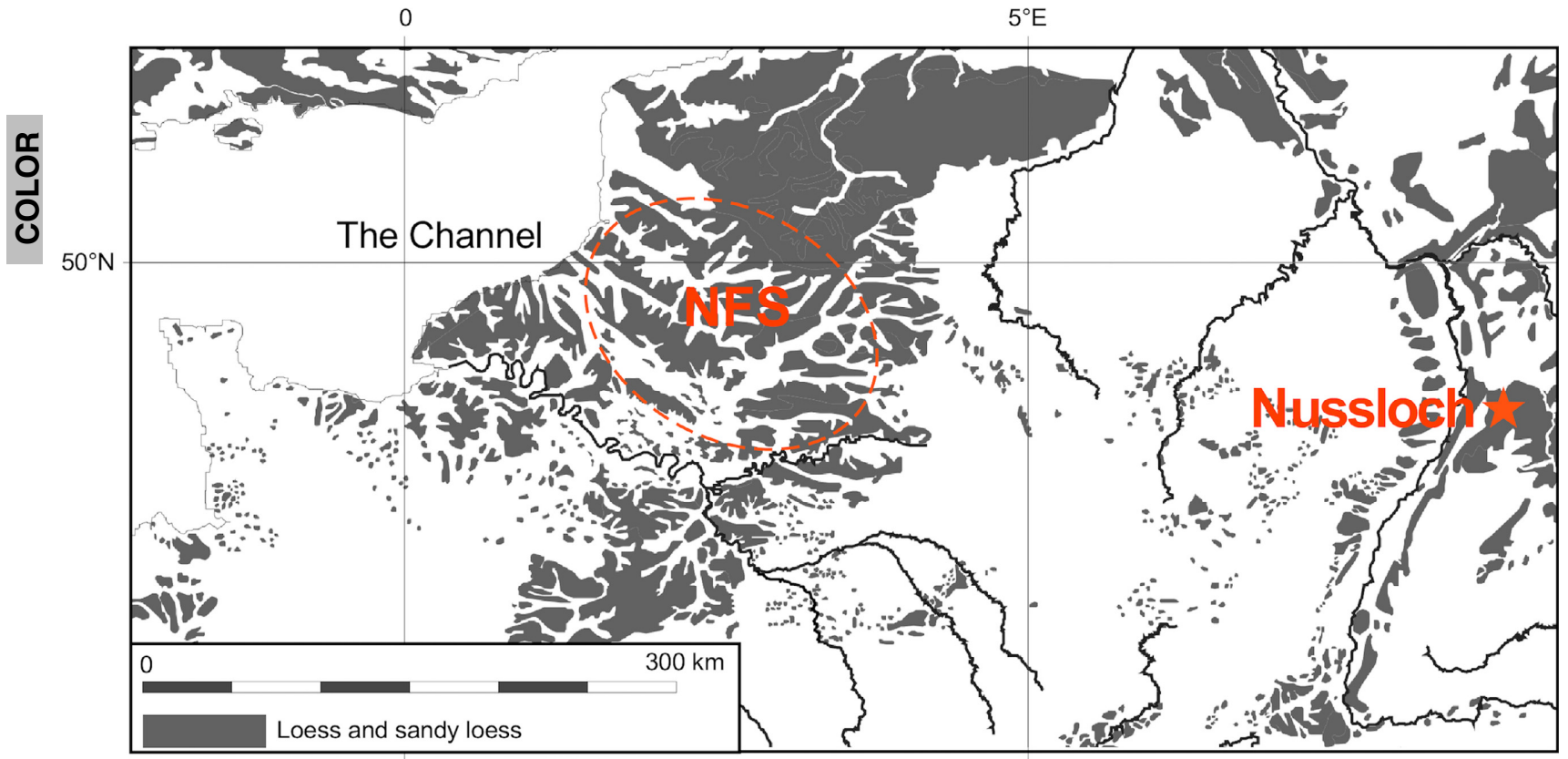

Fig. 1. Map of the loess and sandy loess cover over western Europe with the location of the Nussloch site and of the northern France sequences (NFS) modified from Haase et al. (2007) and Antoine et al. (2016).

(Lohner Boden). This part of the record is characterized by an average sedimentation rate of $0.19 \mathrm{~mm} \mathrm{a}^{-1}$.

The upper part is characterized by a very high sedimen tation rate (average: $0.93 \mathrm{~mm} \mathrm{a}^{-1}$ ) and by a cyclic alternation of typical calcareous loess and tundra gley horizons. Tundra gley horizons were formed by hydromorphic processes and correspond to active layers of former permafrost events. Thus, these horizons indicate the presence of a former permafrost. This interpretation is supported by observations from northwestern France plateau sections in which large ice-wedge cast networks are systematically connected with tundra gley horizons (Antoine et al. 2016). Furthermore, the new radiocarbon chronology of the Nussloch loess sequence (Moine et al. 2017) confirms the correlations of both brown soils and main tundra gley horizons with interstadials identified in Greenland ice-core $\delta^{18} \mathrm{O}$ and dust records.

\section{Sampling strategy}

The 17-m-thick Nussloch profile P8 was sampled at high resolution (5-cm-thick) using the continuous column sampling protocol (Antoine et al. 2009). Two continuous columns of 332 samples were collected in parallel: one $-5 \mathrm{em}$ large producing $300 \mathrm{~g}$ samples for grain-size

analyses and one -50 - em large resulting in -10 L samples $(-10-12 \mathrm{~kg})$ for malacelogieal analyses from which granthes have been extracted.

Grain-size analyses were performed using a Beckman Coulter LS-230 laser particle size analyser following the protocol presented in Antoine et al. (2009). Ten grams of homogenized subsamples was first dispersed by addition of sodium hexametaphosphate $(5 \%)$, then processed overnight in a rotating agitator, and finally sieved at $160 \mu \mathrm{m}$ in order to remove the coarse fraction (calcified roots, $\mathrm{Fe}$ and $\mathrm{Mn}$ concretions and fragments of mollusc shells). Each sample was measured with the Coulter at least three times in order to good reproducibility. The limits of the grain-size classes applied to Nussloch were adjusted using a comparison between classical and laser grain-size analyses from a set of test samples: clay: $\leq 4.6 \mu \mathrm{m}$; coarse silts: 26 to $52 \mu \mathrm{m}$; fine sands: 52 to $160 \mu \mathrm{m}$. A grain-size index (GSI) reflecting the variations in aeolian dynamics throughout the record has been defined as the ratio between the coarse silt fraction $(\%)$ and the fraction of fine silt plus clay (\%) (Antoine et al. 2009).

ECG were extracted from the malacology samples. After wet sieving $(>0.425 \mathrm{~mm})$ of the samples, ECG larger than $0.8 \mathrm{~mm}$ were extracted and counted under a binocular microscope to select mainly Lumbricus material (Canti 1998; Canti \& Piearce 2003). According to Canti \& Piearce (2003), this genus has its calciferous glands very well developed and produces the largest granules (with a diameter $>0.5 \mathrm{~mm}$ ).

\section{Results}

\section{Variation in ECG concentrations}

Figure 2 shows that the variation in the ECG concentrations appears to be correlated with the stratigraphy 


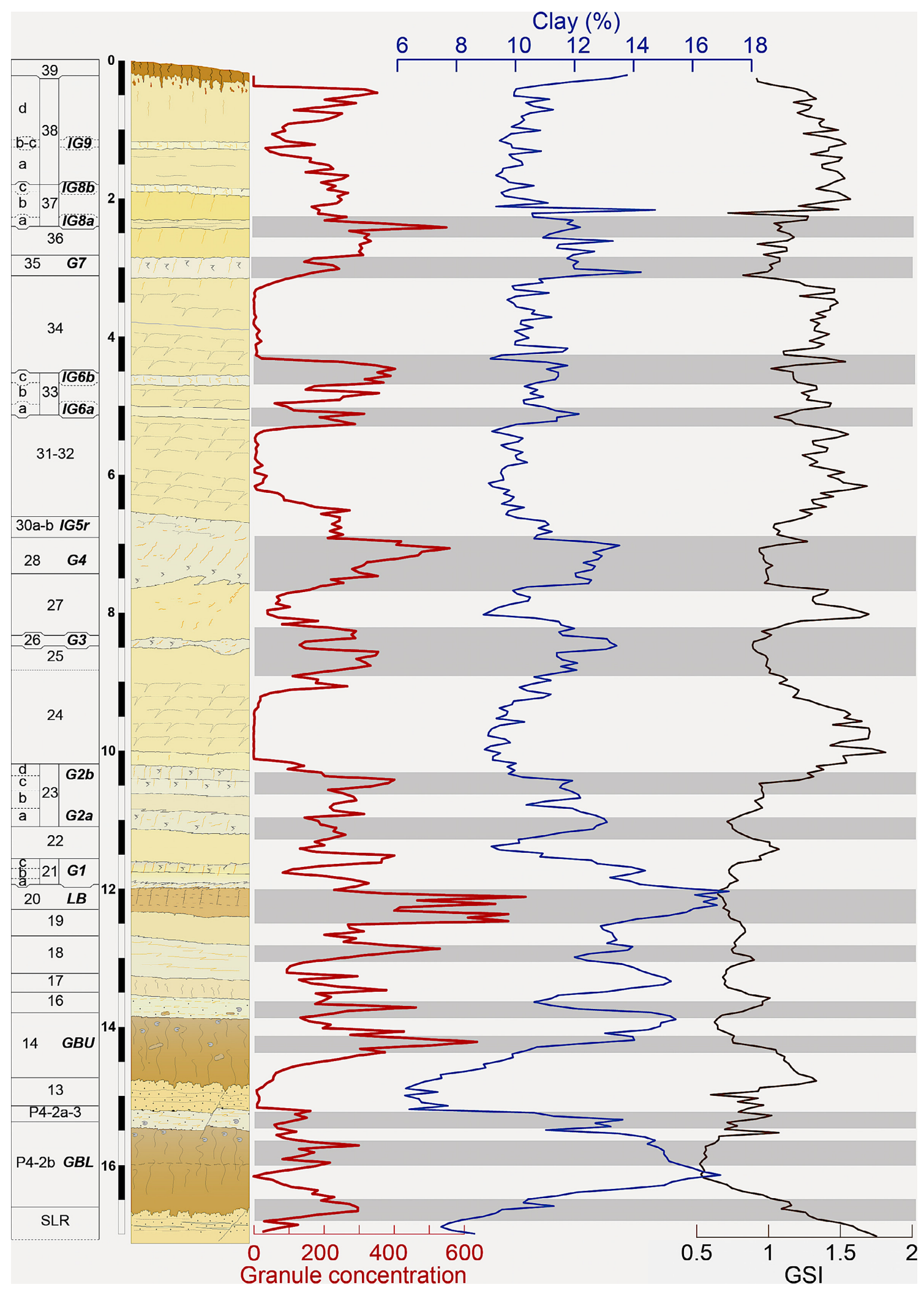

Fig. 2. Pedostratigraphy of the Nussloch profile P8 associated with the earthworm granule concentration (in red), the clay fraction percentage $(<4.6 \mu \mathrm{m}$, blue) and the grain-size index (GSI, brown). Detailed descriptions of the stratigraphy and lithology are available in Antoine et al. (2001, 2009). GBL = Lower Gräselberger Boden (boreal brown soil, Bw horizon); GBU = Upper Gräselberger Boden (boreal brown soil, Bw horizon); $\mathrm{LB}=$ Lohner Boden (arctic brown soil, Bw horizon); $\mathrm{G}=$ major tundra gley (gelic gleysol horizon); $\mathrm{IG}=$ incipient tundra gley; $\mathrm{r}=$ reworked . 
and with both GSI and clay fraction variations. All the data are available in Table S1.

During the Middle Pleniglacial, the highest ECG concentrations are found in boreal and arctic brown soil (GBU and LB) with more than 600 granules per sample. However, the lower boreal brown soil (GBL) recorded a lower granule concentration (around 200), probably due to its higher coarse sand content. P8 is the first profile that provides evidence of the presence of two horizons in the

27 GBL unit (P4-2b), with a stratigraphical limit found in the section at $16 \mathrm{~m}$. The upper part is characterized by a humic horizon associated with a higher percentage of coarse sand $(>160 \mu \mathrm{m})$ compared to the lower part. This observation is coherent with the double peak in the granule concentration. This palaeosol probably developed during two interstadials (GI 14 and 13). The maximal ECG concentrations occur between 15 and $30 \mathrm{~cm}$ below the surface of these palaeosols.

During the Upper Pleniglacial, the maximal concentrations are observed in tundra gley horizons with values

28 between 130 and 400, whereas homogeneous loess units are associated with extremely low ECG concentrations

29 (between 30 and 100 by 10 ). The three laminated loess units are characterized by drastic decreases associated with very low concentrations of large granules (diameter $30>0.8 \mathrm{~mm}$ ) between 0 and 10 .

\section{Grain-size distribution}

The variations in ECG concentration were compared 31 with clay contents and with GSI (ratio between coarse and fine silt+clay). High GSI values imply strong aeolian dynamics and occur within loess units, whereas low GSI values indicate a decrease in dust storms and are correlated within palaeosol formations. GSI highlights relative changes in the aeolian dynamics (Rousseau et al. 2007; Antoine et al. 2009). Throughout the profile P8, GSI varies from 0.5 to 1.9 (Fig. 2). Palaeosols are characterized by the lowest values whereas the highest ones are associated with loess units.

The clay percentage is affected by two processes: (i) weathering of loess leading to soil formation and (ii) variations in aeolian dynamics (highest values corresponding to phases of low sedimentation rates). The clay fraction varies between 6.3 and $17.2 \%$ (Fig. 2). The lowest value is found in unit 13, whereas the highest value is found in the Lohner Boden (unit 20). During the Upper Pleniglacial, the tundra gleys are characterized by higher clay percentages and lower GSI values compared to loess units. The grain-size analyses of profile P8 confirm the cyclic pattern of the loess-palaeosol sequence pedostratigraphy as already shown by Antoine et al. (2009) and Rousseau et al. (2007). Moreover, the comparison between the variations in ECG concentration and in clay

32 percentage shows a medium correlation $(R=0.6)$ as illustrated by Fig. 2 .

\section{Discussion}

Survival strategy and seasonal activity of earthworms during the Last Glacial

The discovery of high ECG concentration in palaeosols formed during the Last Glacial and the good correlation with the pedostratigraphy demonstrate the presence and the survival of earthworm species during this period in western Europe, preferentially during interstadials, as already observed in northern France loess sequences (Prud'homme et al.2015). In this study, a more complete record of ECG concentration variations has been obtained between $\sim 55$ and $20 \mathrm{ka}$ due to the almost continuous sedimentation and high sedimentation rate of the Nussloch sequence, especially for the Upper Pleniglacial (12 m). High large granule concentration in the tundra gley horizons (active layer of a former permafrost) suggests the presence of the earthworm genus Lumbricus (terrestris and rubellus) in permafrost environment. By contrast, the very low concentration or even the lack of large ECG in loess units indicates a drastic decrease in earthworm activity, but not a total absence of earthworms as a few small granules $(0.5$ to $0.8 \mathrm{~mm}$ ) can be found.

According to the literature, Lumbricus species are not considered as freeze-tolerant, and they are not found in modern permafrost (Perel' 1979; Holmstrup 2003; Calderon et al. 2009). However, as already described in the Introduction, Lumbricus is the only earthworm genus able to produce a high quantity of large granules (Bräm 1956; Canti 1998; Canti \& Piearce 2003), and this genus is found in Russia and in Scandinavia (Tiunov et al. 2006; Meshcheryakova \& Berman 2014). The activity of earthworms and the production of granules are directly linked to both soil temperature and humidity and are thus influenced by seasonal climate fluctuations. Nowadays, the maximum activity of earthworms is observed during spring and autumn and can stop the rest of the (Satchell 1967). Experimental studies on endicate that Lumbricus terrestris are inactive when the soil is frozen (Nordström 1975; Rundgren 1975); however, adult individuals are able to survive and their cocoons (egg matrix) are cryo-resistant (Holmstrup \& Zachariassen 1996; Meshcheryakova \& Berman 2014). In Fig. 3, a conceptual model is proposed to explain how earthworms were able to survive during the Last Glacial in a permafrost environment in function of the seasons:

- Spring is associated with the thawing of the upper horizon of the permafrost (active layer), development of vegetation and increases in biological activity. Earthworm populations are growing and their activity is basically concentrated at the surface (feeding). In addition, they are confined to the upper part of the active layer ( 15-30 cm thick), which is coherent with the thickness of the tundra gley horizons en the field 


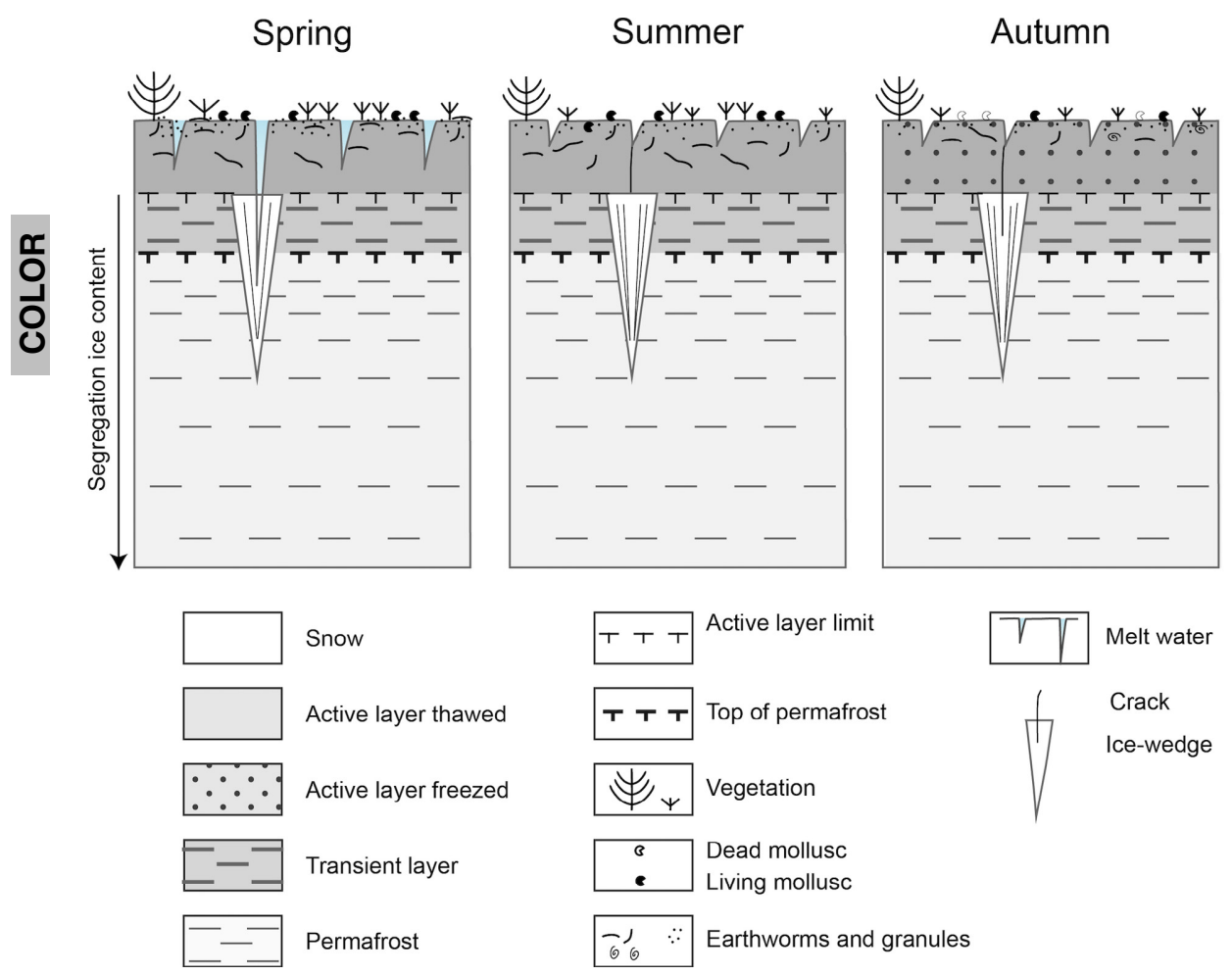

Fig. 3. Schematic model of the different earthworm activity phases in a permafrost environment depending on the season. See on the text for the deseription of the figure.

(French 2007; Burn 2012). The conditions are favourable for the production of granules.

45 - In summer, although the conditions are drier, Lumbricus terrestris are still active (Nordström 1975). The earthworms are mainly found in the upper $5 \mathrm{~cm}$ of the soil due to the high proportion of juveniles, which are not able to dig in the deeper layers (Rundgren 1975).

- In autumn, granule production becomes lower, and the earthworms start to overwinter. The cryo-resistant cocoons are already produced (Holmstrup \& Zachariassen 1996) and are mainly distributed in the upper 7.5

$47 \quad \mathrm{~cm}$ of the soil (Gerard 1967).

- In winter, the biological activity stops and the earthworms are in diapause. The snow cover should be thick enough to protect the soil from extreme temperatures (French 2007). The earthworms are confined to the interface between the thick snow cover and the topsoil. The cocoons protect the eggs until they hatch during the next spring, when the conditions become milder (Tiunov et al. 2006; Meshcheryakova \& Berman 2014).

The earthworms are thus confined to the active layer of the permafrost, greatly reducing the mixing of the

51 granules through depth, allowing an aecurate-chronologiealapproath of these horizons tring $E C G^{14} \mathrm{C}$ dating

52 (Moine et al. 2017). Furthermore, field observations and thin sections indicate an absence of galleries and hiber- nation chambers in these horizons as the earthworms remain mainly at the surface (Rundgren 1975). Moreover, the rate of active horizontal movements (due to locomotion) varies amongst species, but is limited to $14 \mathrm{~m} \mathrm{a}^{-1}$ in the most favourable conditions, and is generally around $4 \mathrm{~m} \mathrm{a}^{-1}$ (Eijsackers 2011; Caro et al. 2013). The effect of dryness on earthworm movements has not been studied so far, yet it is indeed an interesting question. However, it has been shown for a long time that earthworms go into quiescence, a form of resistance, when the soil dries out (Satchell 1967; Bouché 1972). Bearing in mind that dispersal is very costly in terms of survival, due to predation and other risks, it is more likely that earthworms enter into such a form of resistance rather than dispersing during unfavourable conditions.

\section{Comparison between ECG concentration, pedostratigraphy and grain-size distribution}

The good correlation between ECG concentration, clay percentage variations and the stratigraphy (Fig. 2) confirms that earthworms produced the granules during the formation of palaeosols and not after. Granules are thus contemporaneous with the horizons in which they are found. Additionally, the variations in mollusc concentration in the profile P3 of Nussloch (Moine et al. 
2008) show a similar pattern to the ECG variations, especially during the Middle Pleniglacial. The boreal (GBU) and arctic (LB) brown soils as well as the major tundra gleys are associated with the highest ECG 56 abundances (up to 700) and with high molluscan species diversity and individual concentration. As already ebserved in the counting of the ECG in P8, the boreal brown soil (GBL) is characterized by lower molluscan 57 abundances than GBU and LB in P3. The increase in molluscan species diversity in these palaeosols indicates a densification of the vegetation cover from steppe to a herb/shrub tundra environment during the LowerMiddle Pleniglacial transition (Moine et al. 2005).

The vertical distribution of ECG through the palaeosols between about 55 and $35 \mathrm{ka}$ differs from that in the present-day soils (Fig. 4). In the brown soils and tundra gley horizons, the maximum number of ECG is not found at the surface of the soil but 15 to $30 \mathrm{~cm}$ below. However, in present-day soils, earthworms (especially Lumbricus

58 terrestris and L. rubellus) need a land surface to feed and they produce a high concentration of granules within 59 the litter layer (Canti \& Piearce 2003; Canti 2007). This pattern of the ECG concentration suggests that boreal and arctic brown soils result from accretionary soil processes (upbuilding soils; Nikiforoff 1949; Almond \& Tonkin 1999) associated with a low aeolian sedimenta60 tion, which is contemporaneous with weathering processes. This hypothesis is also confirmed by dis tribution of the molluse concentration through the

61 Middle Pleniglacial palaeosels in Nussloch (Moine $e t$ al. 2008, 2011). Indeed, most of the mollusc species found in Nussloch are surface species and do not bury more than $5 \mathrm{~cm}$ in depth to hibernate (Moine et al. 2008). Therefore, loessic sedimentation did not stop completely but only reduced during the palaeosol formation.

Major and incipient tundra gley horizons were developed during the Upper Pleniglacial (Fig. 2). The incipient tundra gley horizons described in the Nussloch loess profiles are associated with high ECG concentrations comparable to major tundra gleys and with an increase in the clay content, especially for IG5, IG6 and IG8a (Fig. 2, units 30a-b, 33a-c, 37a). This pattern is not recorded in the number of individual molluscs, although a decrease in the diversity and a slight increase from 20 to $30 \%$ in the proportion of $S$. oblonga is observed. The comparison between the stratigraphical observations 65 and the variations in ECG concentration suggests that incipient tundra gleys might correspond to rapid and very short climate improvements $(\leq 0.3 \mathrm{ka})$, less intense than the interstadial phases. Based on recent ECG radiocarbon chronology, incipient tundra gleys appear to be correlated with significant decreases in Greenland ice-core dust records (Moine et al. 2017). Moreover, a slight shift between pedostratigraphical limits, ECG concentrations and clay percentage is observed very clearly for the incipient tundra gleys IG5, IG6 and IG8 and for the major tundra gleys G2, G3 and G4 (Fig. 2).
Thus, the increases in ECG concentration and clay percentage seem to record the beginning of a warming phase, associated with an increase in edaphic humidity and a reduction in the sedimentation rate, slightly below the stratigraphical limits, i.e. preceding the development of the tundra gley horizons.

By contrast, the low concentration of large granules and the absence of molluscs in loess units indicate that the conditions were too extreme for earthworm and mollusc activities. The homogeneous loess units (especially units 22 and 23b) are associated with low ECG concentrations (50-150 granules), but not as low as the laminated loess units, in which they are close to zero and not significant (0-10 in $10 \mathrm{~L}$ samples).

This pattern suggests that the climatic conditions during the deposition of homogeneous loess units were not extreme enough (cold, dry and windy) to affect the activity of the earthworm population, in contrast to the mollusc population. Earthworms were thus probably more resistant to extreme conditions than molluscs during the extreme cold phases of the Last Glacial. Indeed, whereas terrestrial molluscs live mainly at the surface of the soil, earthworms live in the soil and feed at the surface. This difference can explain the two patterns of these two expecially during the Upper Pleniglacial. Besides, the deposition of the laminated loess units (units 24, 31-32 and 34) is characterized by a high sedimentation rate $\left(\geq 1 \mathrm{~mm} \mathrm{a}^{-1}\right)$ and by the occurrence of thin sand beds resulting from dust storms able to rework sand grains from the alluvial plain of the Rhine and niveo-aeolian processes (Antoine et al. 2009). An abrupt decrease in ECG concentration is systematically observed in these facies in the Nussloch loess sequence ( 0 to 10 -granules) associated with a decrease in the percentage of clay content and an increase in the GSI. These observations highlight an enhancement of the wind and aeolian dynamics coupled to extreme climatic conditions, which increase the desiccation of the surface. The correlation between the pedostratigraphy of the loess sequence and the NGRIP dust data suggests that these particular horizons are contemporaneous with the Heinrich Stadials HS 3 (around $30 \mathrm{ka}$ ) and HS 2 (between 26 and $24 \mathrm{ka}$ ) (Rasmussen et al. 2014; Moine et al. 2017). Heinrich Events, primary highlight in the Atlantic marine core (Heinrich 1988; Bond \& Lotti 1995), are characterized by a cold and arid climate on the continent (Fletcher et al. 2010; Harrison \& Sanchez Goñi 2010; Menviel et al. 2014). The comparison between the Heinrich layer in the Atlantic marine core and the Greenland ice-core suggests that the Heinrich Events are contemporaneous with dust peaks in the Greenland icecore (Fig. 5). Thus, variations in ECG concentrations through loess-palaeosol sequences can be considered as a new proxy of relative variations in aridity. Moreover, the impact of extreme coldeventsandwind intensityeanalse be recorded when the ECG concentration is close to 0 during Heinrich Events. The same signal (very low to 

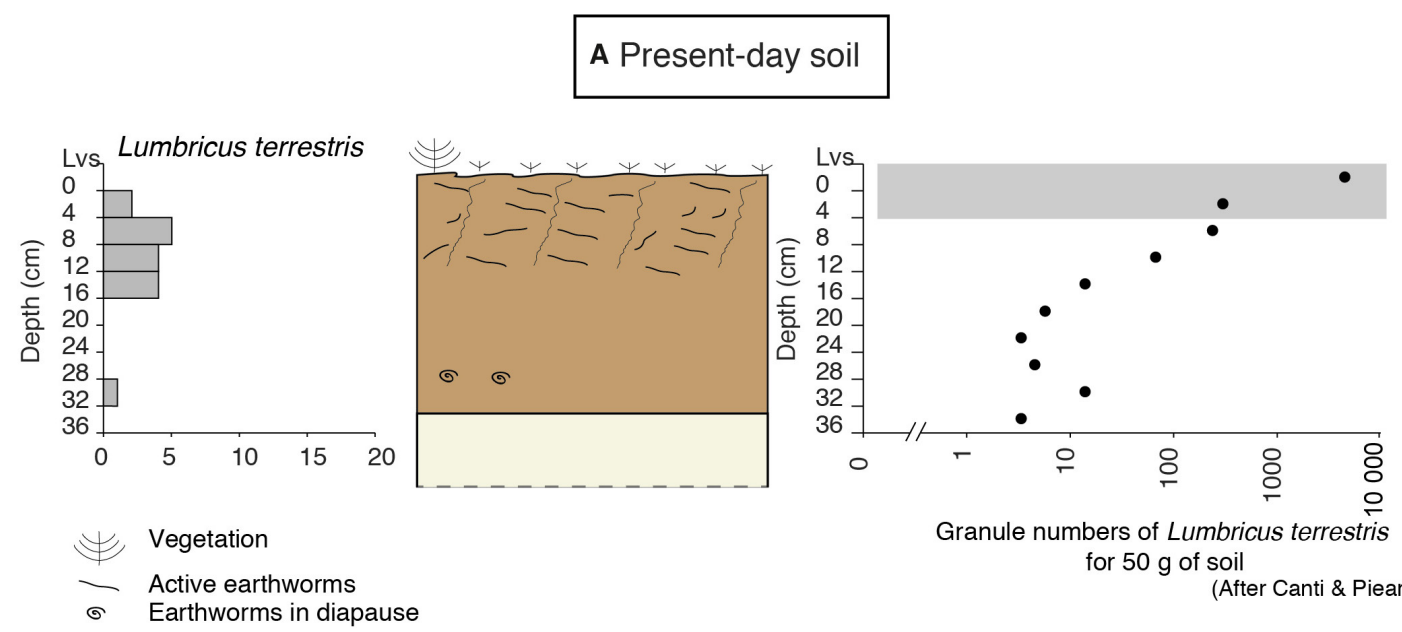

Granule numbers of Lumbricus terrestris for $50 \mathrm{~g}$ of soil

(After Canti \& Piearce 2003)

\section{B Palaeosols from Nussloch profile P8}

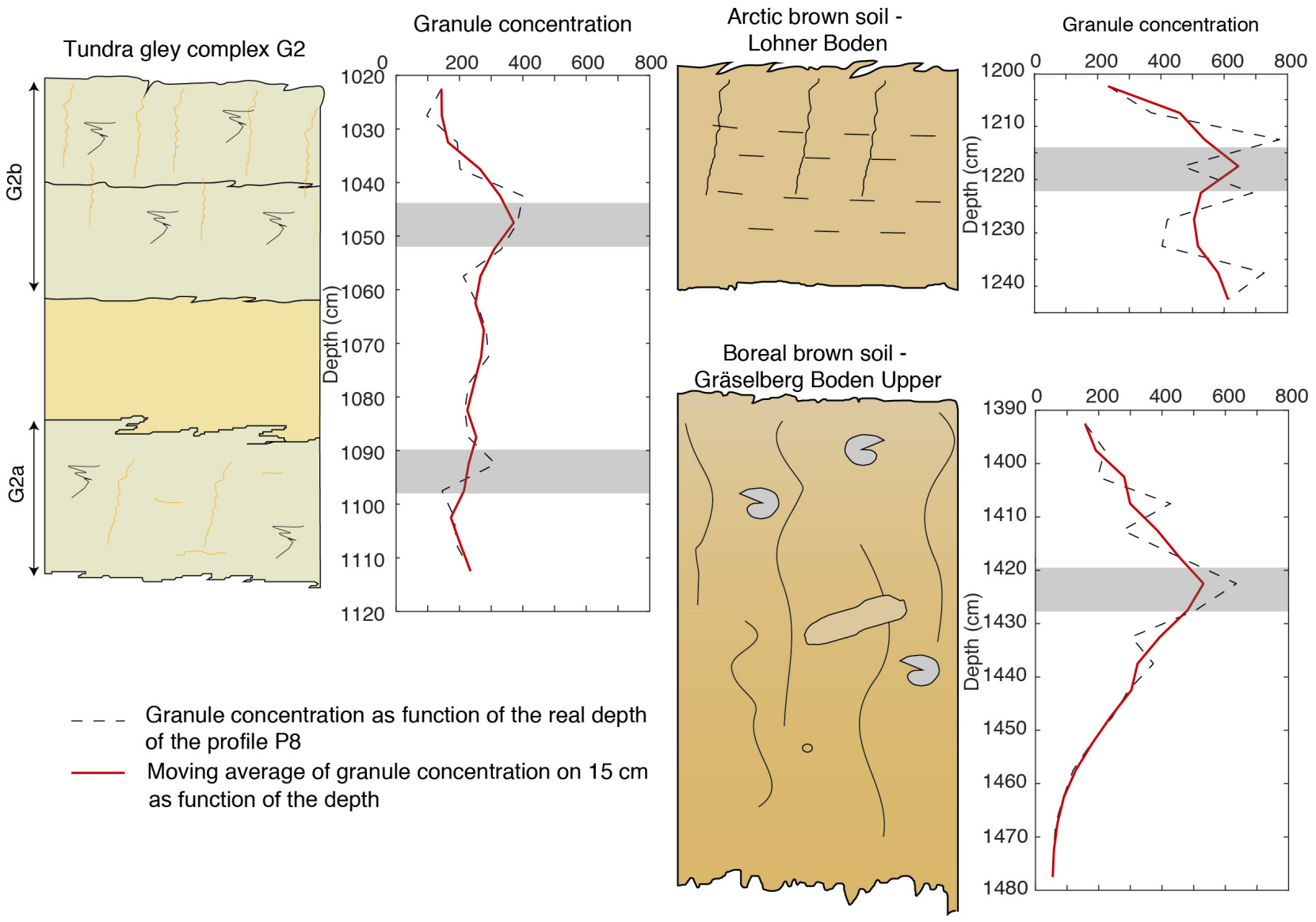

Fig. 4. Distribution of the ECG concentration through(A) present-day experimental soil and (B) three types of palaeosols from the Nussloch loess profile. The distribution of granules through the present-day experimental soil is associated with the distribution of the number of Lumbricus terrestris as a function of depth. The granules were extracted from $50 \mathrm{~g}$ of the soil and around 10000 granules were found in the litter sample(Canti \& Piearce 2003). The ECG were extracted from $10 \mathrm{~L}$ of sediment every $5 \mathrm{~cm}$ through the tundra gley horizons and arctic and boreal brown soils.

zero ECG concentration) is recorded $600 \mathrm{~km}$ away in two northern France loess sequences (Fig. 1) for the same time-span (around $30 \mathrm{ka}$ ), suggesting that variation in ECG concentrations can be used to evidence the response of west European environments to large-scale rapid climatic changes. 


\section{Comparison with Greenland records}

The radiocarbon chronology performed on the ECG confirmed that the two brown soils formed during the Middle Pleniglacial (GBU and LB) can be correlated with Greenland interstadials (GI) 12 and GI 8/7c, and that major tundra gleys G1, G2, G3, G4 and G7 can be correlated with GI 6, GI 5, GI 4, GI 3 and GI 2, respectively (Moine et al. 2017). During this time period, the Greenland interstadials GI 12 and GI 8 are the longest interstadials (2700 and 1700 years, respectively), whereas the duration of the GIs correlated with the development of tundra gley horizons are shorter, between 600 and 200 years. The temperature reconstructions performed on NGRIP indicated an increase between
$8.5{ }^{\circ} \mathrm{C}$ (GI 2) and $15.5{ }^{\circ} \mathrm{C}$ (GI 7), with no particular difference between long and short interstadials in this arctic area (Landais et al. 2004; Capron et al. 2010; Kindler et al. 2014). Moreover, palaeoclimate parameters (temperature and precipitation, Fig. 5) have been estimated from oxygen and carbon stable isotope analyses performed on ECG (Prud'homme et al. 2016, 2018). During the formation of GBU, the air temperature for the five warmest months was $13.0 \pm 4.1^{\circ} \mathrm{C}$ and the mean palaeoprecipitation was $287+223 /-161 \mathrm{~mm}$ $\mathrm{a}^{-1}$, whereas during the formation of the Lohner Boden, the temperature of the warmest season was $11.7 \pm 3.6{ }^{\circ} \mathrm{C}$ and the mean rainfall was $322+236 /-171 \mathrm{~mm} \mathrm{a}^{-1}$ (Prud'homme et al. 2016, 2018). The palaeoenvironmental reconstructions from the coastal Atlantic marine

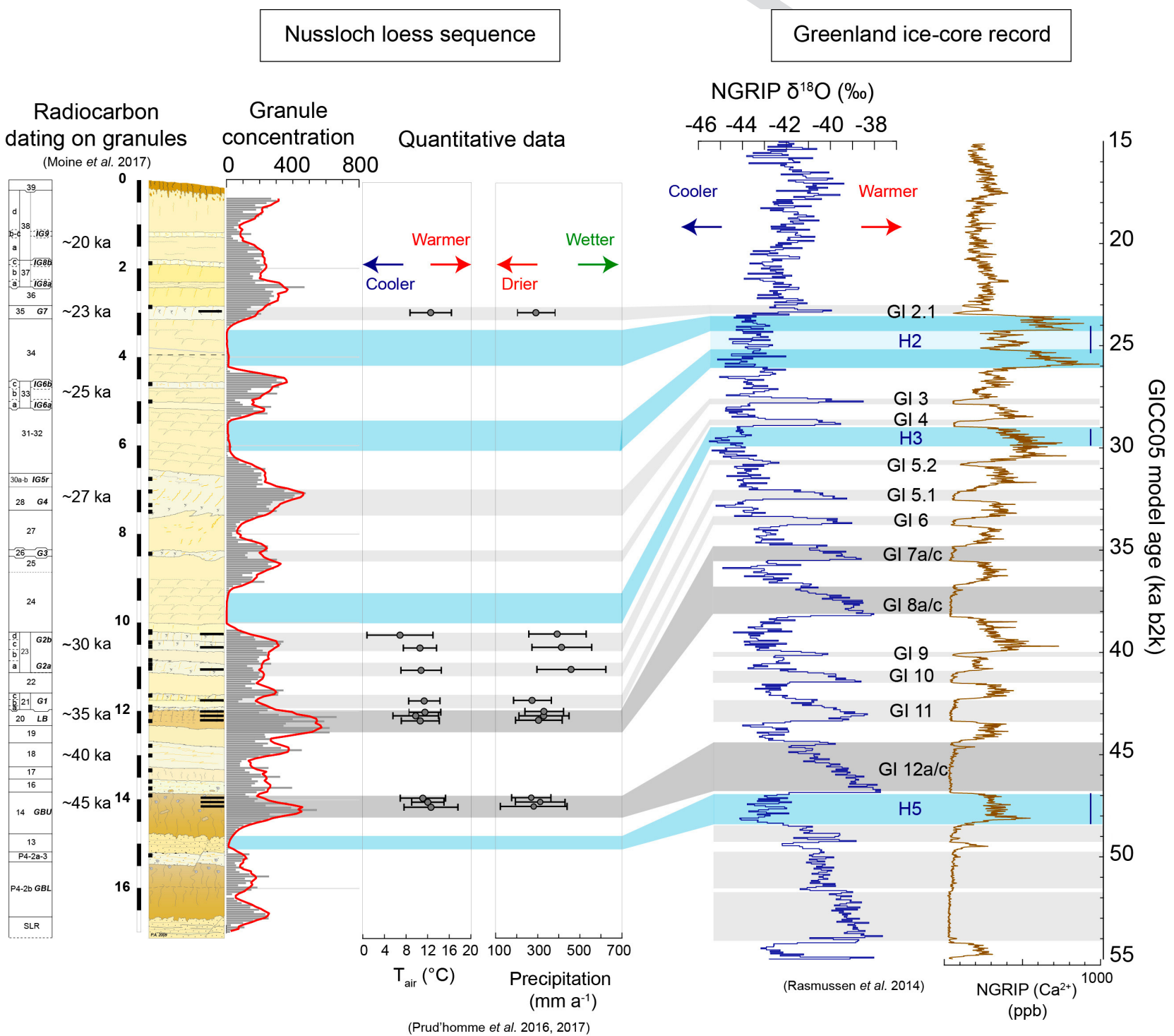

78 Fig. 5. Correlation between ECG concentration and quantitative palaeoclimate parameters (temperature and precipitation; Prud'homme et al. 2016, 2018) of the Nussloch loess sequence with the Greenland ice-core record (Rasmussen et al. 2014) and the Heinrich events (Rasmussen et al. 2016) based on the ECG radiocarbon chronology of the loess sequence (Moine et al. 2017). 
79 core MD04 2845 next to the French coast and located above $45^{\circ} \mathrm{N}$ indicate that GI 12 is characterized by a mild and moderately humid environment with mainly Pinus forest whereas GI 8 is still mild but less humid with a vegetation represented by grassland and dry shrubland (Fletcher et al. 2010).

The difference in humidity between GI 12 and GI 8 recorded in Nussloch loess sequence is also confirmed by the pedostratigraphy. The LB is an arctic brown soil with the presence of cryostructures (platy structure indicating ice-lensing processes), which indicate more humid conditions than in the boreal brown soils (GBU) (Antoine et al. 2009). Furthermore, during the Upper Pleniglacial, palaeoclimate data indicate that tundra gley horizon G2a/b was formed during mild and humid conditions (Fig. 5). The air temperature of the warmest season was $9.4 \pm 4.3{ }^{\circ} \mathrm{C}$ and the mean annual precipitation was 425 $+273 /-201 \mathrm{~mm} \mathrm{a}^{-1}$. These climate conditions are supported by (i) the very high proportion (more than 50\%) of the hygrophilous mollusc taxon Succinella oblonga (Moine et al. 2005, 2008) and by (ii) more intense hydromorphic features, such as stronger reduction, greenish colour and more developed iron oxide precipitation around root tracks (Antoine et al. 2009). The two

81 horizons $\mathrm{G} 2 \mathrm{a}$ and $\mathrm{G} 2 \mathrm{~b}$ of tundra gley $\mathrm{G} 2$ are respectively correlated with GI 5.2 and GI 5.1 (Moine et al. 2017). This interstadial (600 years) is characterized by an increase of $+12.5^{\circ} \mathrm{C}$ prior to the Heinrich Event $\mathrm{H} 3$ (Kindler et al. 2014; Rasmussen et al. 2014). Wetter conditions are also recorded ent the laminated Eifel maar 82 sediments in Germany, where four flooding events were discovered around 30 to $31 \mathrm{ka}$, suggesting intense spring snow-melt events (Sirocko et al. 2015). This period (around 31-30 ka) corresponds to the first step of the maximal expansion of the Fennoscandian ice sheet, implying an increase in moisture eonditions in NW

83 Europe (Hardt et al. 2016; Hughes et al. 2016). This time-span is also characterized by the first considerable 84 increase in typical loess deposition throughout northwestern Europe (Antoine et al. 2016).

\section{Conclusions}

The first continuous record of the variations in large ECG concentration through the Nussloch loess sequence led to the discovery of very high granule concentrations in boreal and arctic brown soils and tundra gleys horizons, whereas loess deposits are distinguished by very low values that are even close to zero in laminated loess units. Generally, the variation in ECG concentration is well correlated with stratigraphical boundaries and variations in clay percentages, suggesting a link with palaeoclimate and palaeoenvironmental changes. Nevertheless, the maximal abundance of ECG is not found at the surface (as in the present-day soil profile) but 15 to $30 \mathrm{~cm}$ deeper. This observation suggests that loess sedimenta- tion was not null during the formation of boreal and arctic brown soils and tundra gleys horizons. Moreover, the high concentration of large granules in the incipient tundra gley horizons indicates that these units may be associated with rapid and short climate improvement but less intense than that during the interstadial phases, which is favourable to earthworm activity. However, the absence of terrestrial molluscs in these horizons suggests that earthworms are more resistant to periods of marked climatic stress (cold and arid conditions) as they can protect themselves by burrowing into the soil, especially in very exposed conditions such as at the top of the Nussloch loess gredas.

Furthermore, the good correlation between the ECG concentration and the clay content in tundra gley horizons suggests that the beginning of the warming associated with the increase in humidity is anterior to the formation of the stratigraphical units and thus to the functioning of the active layer.

The comparison between the high concentration of ECG in palaeosols and the radiocarbon dating confirmed that boreal and arctic brown soils and tundra gley horizons were formed under climatic conditions (interstadial events) associated with the development of biodiversity.

Finally, the three drastic decreases in ECG concentration suggest that they are contemporaneous with peaks of dust recorded in the Greenland ice-core associated with Heinrich Events (H3 and H2). Thus, the absence of large ECG can be interpreted as a new indicator of aridity through the loessic sequence of Nussloch, even though the role of potentially very low temperatures and the increase in wind intensity during these three cold stages should also be considered. This approach could therefore highlight in the future, climatic oscillations that are hardly identifiable in other contexts. Moreover, the same pattern is observed in two loess sequences of northern France $(600 \mathrm{~km}$ to the west) in the same period (30 ka), suggesting a global aridity signal over western Europe. In the future, an investigation of variation in the ECG concentration at the top and at the sides of a greda in loess-palaeosol sequences formed in gentle topography could provide information about the migration of earthworms and their possible refuges during the Last Glacial.

The comparison between ECG concentration, grainsize variations, palaeoclimate data and radiocarbon dating confirms that ECG can be used as a new palaeoenvironmental and palaeoclimate proxy of the Last Glacial in continental environments. Therefore, it can help to better understand the response of terrestrial archives to the millennial climate variations highlighted in ice-cores.

Acknowledgements. - This work received financial support from the LabEx DynamiTe (ANR-11-LABX-0046), as part of the 'Investissements d'Avenir' program. The authors thank the two anonymous reviewers and Jan A. Piotrowski for their constructive comments that helped us to improve the scientific content of this study. 


\section{References}

Almond, P. C. \& Tonkin, P. J. 1999: Pedogenesis by upbuilding in an extreme leaching and weathering environment, and slow loess accretion, south Westland, New Zealand. Geoderma 92, 1-36.

Antoine, P., Coutard, S., Guerin, G., Deschodt, L., Goval, E., Locht, J. L. \& Paris, C. 2016: Upper Pleistocene loess-palaeosol records from Northern France in the European context: environmental background and dating of the Middle Palaeolithic. Quaternary International 411, 4-24.

Antoine, P., Rousseau, D. D., Hatté, C., Zöller, L., Lang, A., Fontugne, M. \& Moine, O. 2002: Événements éoliens rapides dans les loess du pléniglaciaire supérieur weischselien : L'exemple de la séquence de Nussloch Vallée du Rhin-Allemagne. Quaternaire 13, 199-208.

Antoine, P., Rousseau, D. D., Moine, O., Kunesch, S., Hatté, C., Lang, A., Tissoux, H. \& Zöller, L. 2009: Rapid and cyclic aeolian deposition during the Last Glacial in European loess: a high-resolution record from Nussloch, Germany. Quaternary Science Reviews 28, 29552973.

Antoine, P., Rousseau, D. D., Zöller, L., Lang, A., Munaut, H., Hatté, C. \& Fontugne, M. 2001: High-resolution record of the last Interglacial glacial cycle in the Nussloch loess palaeosol sequences, Upper Rhine Area, Germany. Quaternary International 77, 211-229.

Barta, G. 2014: Paleoenvironmental reconstruction based on the morphology and distribution of secondary carbonates of the loesspaleosol sequence at Süttő, Hungary. Quaternary International 319, 64-75.

Becze-Deák, J., Langohr, R. \& Verrecchia, E. P. 1997: Small scale secondary $\mathrm{CaCO}_{3}$ accumulations in selected sections of the European loess belt. Geoderma 76, 221-252.

Bond, G. C. \& Lotti, R. 1995: Iceberg discharges into the north Atlantic on millennial time scales during the last glaciation. Science 267, 10051010.

Bouché, M. B. 1972: Lombriciens de France. Ecologie et Systématique. 671 pp. INRA, Paris.

Bräm, H. 1956: Was sind Arion kinkelini Wenz und A. hochheimensis Wenz. Eclogae Geologicae Helvetiae 49, 593-598.

Briones, M. J. I., López, E., Méndez, J., Rodríguez, J. B. \& Gago-Duport, L. 2008: Biological control over the formation and storage of amorphous calcium carbonate by earthworms. Mineralogical Magazine $72,227-231$.

Burn, C. 2012: Permafrost distribution and stability. In French, H. \& Slaymaker, O. (eds.): Changing Cold Environments: A Canadian Perspective, 126-146. Wiley, Chichester.

Calderon, S., Holmstrup, M., Westh, P. \& Overgaard, J. 2009: Dual roles of glucose in the freeze-tolerant earthworm Dendrobaena octaedra: cryoprotection and fuel for metabolism. Journal of Experimental Biology 212, 859-866.

Canti, M. G. 1998: Origin of calcium carbonate granules found in buried soils and Quaternary deposits. Boreas 27, 275-288.

Canti, M. G. 2007: Deposition and taphonomy of earthworm granules in relation to their interpretative potential in Quaternary stratigraphy. Journal of Quaternary Science 22, 111-118.

Canti, M. G. \& Piearce, T. G. 2003: Morphology and dynamics of calcium carbonate granules produced by different earthworm species. Pedobiologia 47, 511-521.

Capron, E., Landais, A., Chappellaz, J., Schilt, A., Buiron, D., DahlJensen, D., Johnsen, S. J., Jouzel, J., Lemieux-Dudon, B., Loulergue, L., Leuenberger, M., Masson-Delmotte, V., Mayer, H., Oerter, H. \& Stenni, B. 2010: Millennial and sub-millennial scale climatic variations recorded in polar ice cores over the last glacial period. Climate of the Past Discussions 6, 135-183.

Caro, G., Decaëns, T., Lecarpentier, C. \& Mathieu, J. 2013: Are dispersal behaviours of earthworms related to their functional group? Soil Biology and Biochemistry 58, 181-187.

Darwin, C. 1881: The formation of vegetable mould through the action of worms, with observations on their habits. Science os-3, 2626 .

Eijsackers, H. 2011: Earthworms as colonizers of natural and cultivated soil environments. Applied Soil Ecology 50, 1-13.

Fletcher, W. J., Sánchez-Goñi, M. F., Allen, J. R. M., Cheddadi, R., Combourieu-Nebout, N., Huntley, B., Lawson, I., Londeix, L., Magri, D., Margari, V., Müller, U. C., Naughton, F., Novenko, E.,
Roucoux, K. \& Tzedakis, P. C. 2010: Millennial-scale variability during the last glacial in vegetation records from Europe. Quaternary Science Reviews 29, 2839-2864.

French, H. M. 2007: The Periglacial Environment. 478 pp. Wiley, Chichester.

Gago-Duport, L., Briones, M. J. I., Rodríguez, J. B. \& Covelo, B. 2008: Amorphous calcium carbonate biomineralization in the earthworm's calciferous gland: pathways to the formation of crystalline phases. Journal of Structural Biology 162, 422-435.

Gerard, B. M. 1967: Factors affecting earthworms in pastures. Journal of Animal Ecology 36, 235-252.

Haase, D., Fink, J., Haase, G., Ruske, R., Pécsi, M., Richter, H., Altermann, M. \& Jäger, K. D. 2007: Loess in Europe-its spatial distribution based on a European Loess Map, scale 1:2,500,000. Quaternary Science Reviews 26, 1301-1312.

Haesaerts, P., Damblon, F., Gerasimenko, N., Spagna, P. \& Pirson, S. 2016: The Late Pleistocene loess-palaeosol sequence of Middle Belgium. Quaternary International 411, 25-43.

Hardt, J., Lüthgens, C., Hebenstreit, R. \& Böse, M. 2016: Geochronological OSL: and geomorphological investigations at the presumed Frankfurt ice marginal position in northeast Germany. Quaternary Science Reviews 154, 85-99.

Harrison, S. P. \& Sanchez Goñi, M. F. 2010: Global patterns of vegetation response to millennial-scale variability and rapid climate change during the last glacial period. Quaternary Science Reviews 29 , 2957-2980

Heinrich, H. 1988: Origin and consequences of cyclic ice rafting in the Northeast Atlantic Ocean during the past 130,000 years. Quaternary Research 29, 142-152.

Hodson, M. E., Benning, L. G., Demarchi, B., Penkman, K. E. H., Rodriguez-Blanco, J. D., Schofield, P. F. \& Versteegh, E. A. A. 2015: Biomineralisation by earthworms - an investigation into the stability and distribution of amorphous calcium carbonate. Geochemical Transactions 16, 1-16.

Holmstrup, M. 1994: Physiology of cold hardiness in cocoons of five earthworm taxa Lumbricidae: Oligochaeta. Journal of Comparative Physiology B 164, 222-228.

Holmstrup, M. 2003: Overwintering adaptations in earthworms. Pedobiologia 47, 504-510.

Holmstrup, M. \& Zachariassen, K. E. 1996: Physiology of cold hardiness in earthworms. Comparative Biochemistry and PhysiologyA Physiology 115, 91-101.

Hughes, A. L. C., Gyllencreutz, R., Lohne, Ø. S., Mangerud, J. \& Svendsen, J. I. 2016: The last Eurasian ice sheets - a chronological database and time-slice reconstruction, DATED-1. Boreas 45, 1-45.

Jänsch, S., Steffens, L., Höfer, H., Horak, F., Roß-Nickoll, M., Russell, D., Toschki, A. \& Römbke, J. 2013: State of knowledge of earthworm communities in German soils as a basis for biological soil quality assessment. Soil Organisms 85, 215-233.

Kerney, M. P. 1971: A Middle Weichselian deposit at Halling, Kent. Proceedings of the Geologists' Association 82, 1-11.

Kindler, P., Guillevic, M., Baumgartner, M., Schwander, J., Landais, A. \& Leuenberger, M. 2014: Temperature reconstruction from 10 to 120 $\mathrm{kyr} \mathrm{b} 2 \mathrm{k}$ from the NGRIP ice core. Climate of the Past 10, 887-902.

Landais, A., Caillon, N., Goujon, C., Grachev, A. M., Barnola, J. M., Chappellaz, J., Jouzel, J., Masson-Delmotte, V. \& Leuenberger, M. 2004: Quantification of rapid temperature change during DO event 12 and phasing with methane inferred from air isotopic measurements. Earth and Planetary Science Letters 225, 221-232.

Leger, M. 1990: Loess landforms. Quaternary International 7-8, 53-61. Mathieu, J. \& Davies, T. J. 2014: Glaciation as an historical filter of below-ground biodiversity. Journal of Biogeography 41, 1204 1214.

Mazenot, G. 1956: Recherches sur les faunes malacologiques du loess recent wurmien et de divers limons terrestres holocenes dans le sudest de la France. Societe Linnéenne de Lyon 25, 9-24.

Meijer, T. 1985: The pre-Weichselian nonmarine molluscan fauna from Maastricht-Belvédère Southern Limburge, the Netherlands. Analecta Praehistorica Leidensia 18, 75-103.

Meijs, E. P. M. 2011: The Veldwezelt site province of Limburg, Belgium: environmental and stratigraphical interpretations. Geologie en Mijnbouw/Netherlands Journal of Geosciences 90, 73-94. 
Menviel, L., Timmermann, A., Friedrich, T. \& England, M. H. 2014: Hindcasting the continuum of Dansgaard-Oeschger variability: mechanisms, patterns and timing. Climate of the Past 10, 63-77.

Meshcheryakova, E. N. \& Berman, D. I. 2014: Cold hardiness and geographic distribution of earthworms Oligochaeta, Lumbricidae, Moniligastridae. Entomological Review 94, 486-497.

Meszner, S., Fuchs, M. \& Faust, D. 2011: Loess-Palaeosol-Sequences from the loess area of Saxony Germany. E\&G Quaternary Science Journal 60, 47-65.

Meszner, S., Kreutzer, S., Fuchs, M. \& Faust, D. 2013: Late Pleistocene landscape dynamics in Saxony, Germany: paleoenvironmental reconstruction using loess-paleosol sequences. Quaternary International 296, 94-107.

Moine, O. 2008: West-European malacofauna from loess deposits of the Weichselian Upper Pleniglacial: compilation and preliminary analysis of the database. Quaternaire 19, 11-29.

Moine, O., Antoine, P., Deschodt, L. \& Sellier-Segard, N. 2011: Enregistrements malacologiques à haute résolution dans les loess et les gleys de toundra du pléniglaciaire weichselien supérieur: premiers exemples du nord de la france. Quaternaire 22, 307-325.

Moine, O., Antoine, P., Hatté, C., Landais, A., Mathieu, J., Prud'homme, C. \& Rousseau, D. D. 2017: The impact of Last Glacial climate variability in west-European loess revealed by radiocarbon dating of fossil earthworm granules. Proceedings of the National Academy of Sciences of the United States of America 114, 6209-6214.

Moine, O., Rousseau, D. D. \& Antoine, P. 2005: Terrestrial molluscan records of Weichselian Lower to Middle Pleniglacial climatic changes from the Nussloch loess series Rhine Valley, Germany. The impact of local factors. Boreas 34, 363-380.

Moine, O., Rousseau, D. D. \& Antoine, P. 2008: The impact of Dansgaard-Oeschger cycles on the loessic environment and malacofauna of Nussloch Germany: during the Upper Weichselian. Quaternary Research 70, 91-104.

Nikiforoff, C. C. 1949: Weathering and soil evolution. Soil Science 67, 219-230.

Nordström, S. 1975: Seasonal activity of lumbricids in Southern Sweden. Oikos 26, 307-315.

Nuutinen, V. \& Butt, K. R. 2009: Worms from the cold: lumbricid life stages in boreal clay during frost. Soil Biology and Biochemistry 41, $1580-1582$.

Pecsi, M. 1990: Loess is not the accumulation of dust. Quaternary International 7-8, 1-21.

Perel', T. S. 1979: Rasprostranenie i zakonomernosti raspredeleniâ doždevyh červejfauny SSSR sopredelitel'nymi tablicami Lumbricidae $i$ drugih Megadrili. Nauka, Moskva.

Prud'homme, C., Antoine, P., Moine, O., Turpin, E., Huguenard, L., Robert, V. \& Degeai, J.-P. 2015: Earthworm calcite granules: a new tracker of millennial-timescale environmental changes in Last Glacial loess deposits. Journal of Quaternary Science 30, 529-536.

Prud'homme, C., Lécuyer, C., Antoine, P., Moine, O., Hatté, C., Fourel, F., Amiot, R., Martineau, F. \& Rousseau, D. D. 2018: $\mathrm{d}^{13} \mathrm{C}$ signal of earthworm calcite granules: a new proxy for palaeoprecipitation reconstructions during the Last Glacial in Western Europe. Quaternary Science Reviews 179, 158-166.

Prud'homme, C., Lécuyer, C., Antoine, P., Moine, O., Hatté, C., Fourel, F., Martineau, F. \& Rousseau, D. D. 2016: Palaeotemperature reconstruction during the Last Glacial from $\delta^{18} \mathrm{O}$ of earthworm calcite granules from Nussloch loess sequence, Germany. Earth and Planetary Science Letters 442, 13-20.

Rasmussen, L. M. \& Holmstrup, M. 2002: Geographic variation of freeze-tolerance in the earthworm Dendrobaena octaedra. Journal of
Comparative Physiology B: Biochemical, Systemic, and Environmental Physiology 172, 691-698.

Rasmussen, S. O., Bigler, M., Blockley, S. P., Blunier, T., Buchardt, S. L., Clausen, H. B., Cvijanovic, I., Dahl-Jensen, D., Johnsen, S. J., Fischer, H., Gkinis, V., Guillevic, M., Hoek, W. Z., Lowe, J. J., Pedro, J. B., Popp, T., Seierstad, I. K., Steffensen, J. P., Svensson, A. M., Vallelonga, P., Vinther, B. M., Walker, M. J. C., Wheatley, J. J. \& Winstrup, M. 2014: A stratigraphic framework for abrupt climatic changes during the Last Glacial period based on three synchronized Greenland ice-core records: refining and extending the INTIMATE event stratigraphy. Quaternary Science Reviews 106, 14-28.

Rasmussen, T. L., Thomsen, E. \& Moros, M. 2016: North Atlantic warming during Dansgaard-Oeschger events synchronous with Antarctic warming and out-of-phase with Greenland climate. Scientific Reports 6, 20535

Remy, H. 1968: Zur Stratigraphie und Klimaentwicklung des jüngeren Pleistozäns in Mittel-und Westeuropa unter besonderer Berücksichtigung des Lösses. Decheniana 121, 121-145.

Renssen, H., Kasse, C., Vandenberghe, J. \& Lorenz, S. J. 2007: Weichselian Late Pleniglacial surface winds over northwest and central Europe: a model-data comparison. Journal of Quaternary Science 22, 281-293.

Rousseau, D. D., Boers, N., Sima, A., Svensson, A., Bigler, M., Lagroix, F., Taylor, S. \& Antoine, P. 2017: MIS3 \& 2: millennial oscillations in Greenland dust and Eurasian aeolian records - a paleosol perspective. Quaternary Science Reviews 139, 99-113.

Rousseau, D. D., Sima, A., Antoine, P., Hatté, C., Lang, A. \& Zöller, L. 2007: Link between European and North Atlantic abrupt climate changes over the last glaciation. Geophysical Research Letters 34, L22713.

Rundgren, A. S. 1975: Vertical distribution of Lumbricids in Southern Sweden. Oikos 26, 299-306.

Satchell, J. 1967: Lumbricidea. In Burges, A. \& Raw, F. (eds.): Soil Biology, 259-322. Academic Press, London.

Schirmer, W. 2012: Rhine loess at Schwalbenberg II-MIS 4 and 3. $E \& G$ Quaternary Science Journal 61, 32-47.

Schirmer, W. 2016: Late Pleistocene loess of the Lower Rhine. Quaternary International 411, 44-61.

Sirocko, F., Knapp, H., Dreher, F., Förster, M. W., Albert, J., Brunck, H., Veres, D., Dietrich, S., Zech, M., Hambach, U., Röhner, M., Rudert, S., Schwibus, K., Adams, C. \& Sigl, P. 2015: The ELSAvegetation-stack: reconstruction of landscape evolution zones LEZ: from laminated Eifel maar sediments of the last 60,000 years. Global and Planetary Change 142, 108-135.

Tiunov, A. V., Hale, C. M., Holdsworth, A. R. \& Vsevolodova-Perel, T. S. 2006: Invasion patterns of Lumbricidae into the previously earthworm-free areas of northeastern Europe and the western Great Lakes region of North America. Biological Invasions Belowground: Earthworms as Inwasive Species 8, 1223-1234.

\section{Supporting Information}

Additional Supporting Information may be found in the online version of this article at http://www.boreas.dk.

Table S1. Numerical data of granule counting and granulometry analysis (clay content $<4.6 \mu \mathrm{m}$, coarse sand content $>160 \mu \mathrm{m}$ ) of Nussloch profile $\mathrm{P} 8$. 